ORIGINAL ARTICLE

\title{
Environmental factors as drivers for macroinvertebrate and diatom diversity in Alpine lakes: New insights from the Stelvio National Park (Italy)
}

\author{
Angela BOGGERO,${ }^{1 *}$ Silvia ZAUPA, ${ }^{1}$ Simona MUSAZZI, ${ }^{1}$ Michela ROGORA, ${ }^{1}$ Elzbieta DUMNICKA,${ }^{2}$ Andrea LAMI \\ ${ }^{1}$ CNR-Water Research Institute (IRSA), Corso Tonolli 50, 28922 Verbania Pallanza, Italy; ${ }^{2}$ Institute of Nature Conservation, Polish \\ Academy of Sciences, 31-120 Krakow, Poland
}

\begin{abstract}
Information on the biodiversity of high altitude lakes in the Stelvio National Park was scarce and fragmentary, in most cases limited to a few studies on a single biological issue. To fill this gap, a multidisciplinary research program was established in 2011 to investigate macroinvertebrates, diatoms, and water chemistry in 8 high altitude lakes within the boundaries of the Park (Rhaetian Alps, Eastern Alps). The results of this study were compared with data on biological assemblages and chemical parameters of Alpine lakes in the Pennine-Lepontine Alps (Western Alps), to evaluate the role of local drivers with respect to regional ones. This comparison was possible thanks to the adoption of standardized sampling methodologies developed since the ' 90 s by the National Research Council-Water Research Institute (Verbania), in collaboration with several European Research centers. Despite located in a restricted geographical area, the lakes of the Stelvio National Park showed a high variability of chemical composition, and of sensitivity to acidification, lower than that of the Pennine-Lepontine Alpine lakes. Macroinvertebrate and diatom taxa were ubiquitous and frequent along the Alps, and mainly represented by cold-stenothermal species. Richness, Shannon, Simpson, and Pielou indices applied to phyto- and zoobenthos highlighted significantly lower values in Stelvio National Park lakes than in those of the Pennine-Lepontine Alps for macroinvertebrates, while no significant differences were found for diatoms. Two groups of lakes were identified by Cluster Analysis, mainly on the basis of major ion concentrations. Canonical Correspondence Analysis showed that the macroinvertebrate assemblage of the lakes studied is driven mainly by altitude and lake surface, and, to a lesser extent, by nutrient content. On the contrary, $\mathrm{pH}$ and acid-related variables played a secondary role for diatoms, while nutrients and, more in general, ionic content had significant effects on their species composition. Overall, the results of this first investigation showed that the high elevation of these lakes affects their macroinvertebrate assemblages, while their diatom communities are comparable throughout the Alps.
\end{abstract}

\section{INTRODUCTION}

Most of the lakes and streams located in the headwaters of catchments are ecosystems of high quality due to their low nutrients' concentrations. Alpine lakes are characterized by unique physiographic, morphometric, hydrological, and edaphic characteristics. They are mainly fed by melting snowfields and glaciers. These features make them unstable systems, often affected by human pressures, air pollution, and climate change (Catalán et

Corresponding author: angela.boggero@cnr.it

Key words: Chemistry; diversity indices; ecology; high altitude lakes; morphometry.

Edited by: Giampaolo Rossetti, University of Parma, Italy.

Received: 1 October 2018.

Accepted: 31 January 2019.

This work is licensed under a Creative Commons Attribution NonCommercial 4.0 License (CC BY-NC 4.0).

${ }^{\circ}$ Copyright: the Author(s), 2019

Licensee PAGEPress, Italy

J. Limnol., 2019; 78(2): 147-162

DOI: 10.4081/jlimnol.2019.1863 al., 2006; Kwandrans, 2007). Furthermore, alpine freshwaters exhibit a very low biodiversity that includes few species, most of which rare or sensitive. Being adapted to extreme conditions, these organisms are particularly vulnerable to environmental changes (Füreder et al., 2006; Marchetto et al., 2009; ČiamporováZat'ovičová et al., 2010; de Mendoza and Catalan, 2010). For these reasons, alpine lakes have been widely used as early-warning systems to study the effect of anthropogenic stressors (Battarbee et al., 2009).

These remote ecosystems are indeed no longer in pristine conditions, because environmental changes are affecting their water quality and biota, as well as their structure and functioning (Catalán et al., 2009). Alpine lakes serve as a refuge for glacial relicts, fragile organisms whose persistence in actively reproductive populations can be strongly influenced by several stressors (eutrophication, acidification, toxic pollution, climate change, and fish introduction). Therefore, these stressors are also potentially affecting the lakes functioning and services (King et al., 2000; Lods-Crozet et al., 2012). As a result, biodiversity (with its functional role related to changes in the state of a lake, regime shift and resilience) and its monitoring have become an important tool in target-oriented planning, being useful also to control performances of tailor-made measures and programs in the area of water management (Bennion et al., 2012; Kelly et al., 2012). 
Notwithstanding the multiple statements above mentioned, most of the Alpine lakes (especially those located in mountain and alpine areas) are not included in monitoring programs foreseen by the Water Framework Directive because of their comparatively small dimensions (below $0.5 \mathrm{~km}^{2}$ in surface). However, these fragile ecosystems require an appropriate surveillance within the national monitoring programs. Only long-term data series can provide an adequate and robust database to develop targeted researches to assess anthropogenic climate changes, to find solutions, and to evaluate adaptive strategies to climate warming (Jacobsen et al., 2012). In the near future, alpine lakes will become strategic for water management because of their pivotal role in the regulation of water balance, and as secondary and relevant source/sink of pollutants to lowland ecosystems, with large impacts on water quality and usage.

In view of the above stated, in 2011-2012 a research study was carried out by the CNR-Water Research Institute (CNR-IRSA), formerly CNR-Institute of Ecosystem Study (CNR-ISE), in the Stelvio National Park (SNP, Rhaetian Alps, Italy), to evaluate the ecological status of some lacustrine environments on the base of their chemical and biological characteristics. Macroinvertebrates and diatoms, considered as key groups for monitoring programs since the '70s (Descy and Coste, 1991; Rosenberg and Resh, 1993), were employed. The study was performed in the framework of the SHARE Stelvio, an interdisciplinary program for detecting early evidences of climate change in the SNP. In the past, few research projects were carried out on lakes in the Park area, restricted to specific issues such as macroinvertebrates (Dell'Uomo et al., 1980) and chemistry in Lake Bianco (Giussani et al., 1986), or chironomids of temporary lakes at the glacier's mouth (Forasacco, 1998-1999). In general, the data on diatoms are scarce for the Rhaetian Alps (Rotta et al., 2018). To our knowledge, this study represents the first attempt to ecologically characterize the lakes of the SNP considering both chemical and biological aspects.

The present study contributes to expand the list of macroinvertebrates and diatoms species for the Italian Alps, in particular, by extending the knowledge on water chemistry and biodiversity of high altitude lakes in the SNP area, so far only studied from a glaciological and geomorphological perspective. The improved knowledge on the aquatic biodiversity of this mountain range allows to highlight the conservation value of the high altitude lakes and of their natural and semi-natural habitats, with the final aim to protect and maintain their biodiversity. This is in line with the requirements of the European Regulations (Habitat Directive 92/43/EEC).

Moreover, the extreme environmental conditions and the altitudinal isolation of the lakes studied, make them excellent model systems: i) to compare the results obtained from the present study with a larger data set of lakes in the Pennine-Lepontine Alps to test weather varied lithological, geographical and hydrological characteristics, and varied lake and catchment morphological features may induce different macroinvertebrates and diatoms assemblages; ii) to test the environmental factors structuring the assemblages of macroinvertebrates and diatoms in the SNP lakes highlighting their significance at local or global scale, and the sensitivity of these environments under changing climatic scenarios.

\section{METHODS}

\section{Study area}

A bi-partitioning system, named International Standardized Mountain Subdivision of the Alps (ISMSAI, SOIUSA in Italian), is actually in use in Italy for classifying the Alps on the base of their geography and toponymy (Marazzi, 2005). This system recognizes the Western and the Eastern Alps. The latter includes the Rhaetian Alps (Lombardy, Italy) studied in this paper.

The SNP (Fig. 1), located on the Rhaetian Alps, extends along $1307 \mathrm{~km}^{2}$ over the Lombardy and Trentino Alto Adige Regions, being one of the largest protected area in Italy and in the Southern side of the Alps. Our research was focused on the Lombard sector of the Park, covering an area of about $600 \mathrm{~km}^{2}$. Based on a detailed remote analysis of the SNP area (Salerno et al., 2014), 8 glacial lakes, placed above the local tree line along an altitudinal range between 2400 and $2900 \mathrm{~m}( \pm 200 \mathrm{SD})$ asl, were selected. These lakes (Tab. 1), referred in the paper as Rhaetian Alps lakes (R Alps), were sampled in 2011 during the ice-free season (June-July). R Alps have a median catchment area of $0.19 \mathrm{~km}^{2}$, and surface areas between 0.001 and $0.075 \mathrm{~km}^{2}$. Catchments are mainly formed by metamorphic rocks, with a prevalence of mica schists and gneiss. Lakes Manzina, P1 Rosole, and Bianco have a glacier in their watersheds. Lake Rosole is characterized by tourism and livestock grazing impacts, and Lake Nero by the presence of a cowshed.

\section{Field and lab procedures}

The sampling strategies followed the European standardized water quality monitoring protocols and the sampling guidelines for high altitude lakes (ICP Waters Programme Centre, 1996, 2010; Boggero et al., 2011; CEN, 2003; UNI, 2014). The procedures, used since the ' 90 s at the Water Research Institute (CNR-IRSA) in Verbania, were modified for the specific conditions of the study area.

Water for chemical analyses was sampled at the lake surface or at the outlet, using $0.5 \mathrm{~L}$ polyethylene bottles, 
and, to reduce the possibility of unwanted chemical reactions, stored at dark at $4^{\circ} \mathrm{C}$ until laboratory analyses. On the same occasion, water temperature was measured by a digital thermometer in the same place where chemical samples were taken. Conductivity, $\mathrm{pH}$, alkalinity (using the Gran method for acidimetric titration), ammonium, total nitrogen $(\mathrm{TN})$, reactive $(\mathrm{RP})$ and total phosphorous (TP), and reactive silica (spectrophotometry), sulphate, nitrate, chloride, calcium, magnesium, sodium, potassium (ion chromatography), and total organic carbon (TOC) (high temperature catalytic combustion) were measured for each sample. Chemical analyses were performed according to standard methods for freshwater samples (APHA, AWWA, WEF, 2005; APAT IRSA-CNR, 2003) and following the provisions of the ICP Waters Programme Manual for surface water monitoring (ICP Waters Programme Center, 2010). Both internal and external quality controls were

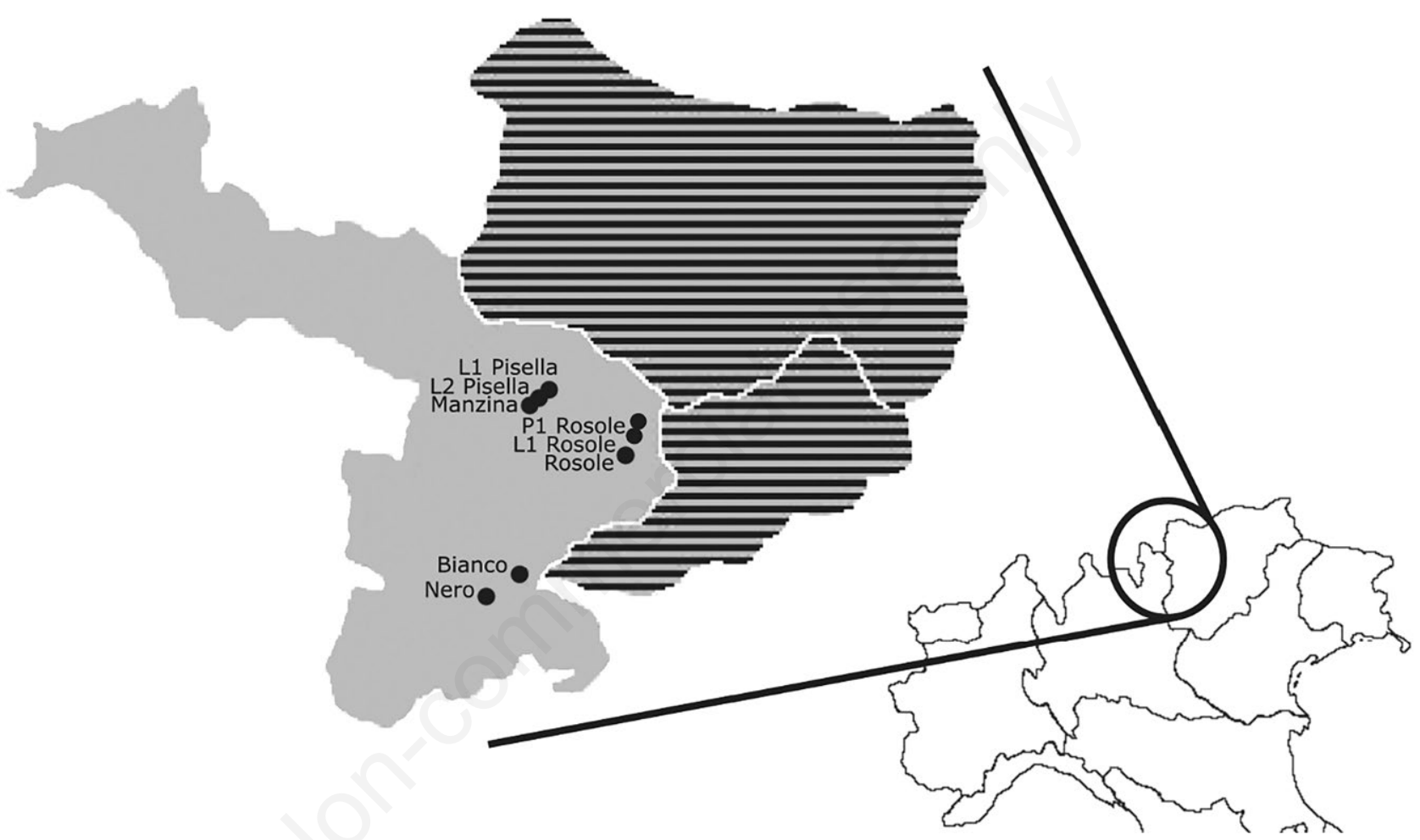

Fig. 1. Location of the Stelvio National Park and of lakes along the Alps. In grey, the sector of the Park where the present study was performed.

Tab. 1. Geographical features and morphometry of the sampled lakes. Geographical data derived from Salerno et al. (2014).

\begin{tabular}{|c|c|c|c|c|c|c|c|c|}
\hline \multirow[t]{2}{*}{ Lake name } & \multirow{2}{*}{$\begin{array}{l}\text { Altitude } \\
\text { (m a.s.l.) }\end{array}$} & \multicolumn{2}{|c|}{ Coordinates DMS } & \multirow{2}{*}{$\begin{array}{l}\text { Lake area } \\
\qquad\left(\mathrm{km}^{2}\right)\end{array}$} & \multirow{2}{*}{$\begin{array}{c}\text { Catchment area } \\
\qquad\left(\mathrm{km}^{2}\right)\end{array}$} & \multirow{2}{*}{$\begin{array}{c}\text { Glacier } \\
(\%)\end{array}$} & \multirow{2}{*}{$\begin{array}{c}\text { Bare rock } \\
\qquad(\%)\end{array}$} & \multirow{2}{*}{$\begin{array}{c}\text { Alpine meadows } \\
(\%)\end{array}$} \\
\hline & & Lat $\mathbf{N}$ & Long E & & & & & \\
\hline Rosole & 2450 & $46^{\circ} 24^{\prime} 47.30^{\prime \prime}$ & $10^{\circ} 35^{\prime} 06.08^{\prime \prime}$ & 0.0028 & 0.151 & - & 81 & 17 \\
\hline Manzina & 2784 & $46^{\circ} 26^{\prime} 14.55^{\prime \prime}$ & $10^{\circ} 31^{\prime} 55.86^{\prime \prime}$ & 0.0244 & 0.832 & 0.14 & 71 & 26 \\
\hline P1 Rosole & 2857 & $46^{\circ} 25^{\prime} 55.91^{\prime \prime}$ & $10^{\circ} 35^{\prime} 39.39^{\prime \prime}$ & 0.0028 & 0.184 & 14.08 & - & - \\
\hline L1 Rosole & 2834 & $46^{\circ} 25^{\prime} 31.40^{\prime \prime}$ & $10^{\circ} 35^{\prime} 24.42^{\prime \prime}$ & 0.0013 & 0.159 & - & - & - \\
\hline L1 Pisella & 2851 & $46^{\circ} 26^{\prime} 21.69^{\prime \prime}$ & $10^{\circ} 32^{\prime} 18.79^{\prime \prime}$ & 0.0029 & 0.072 & - & - & - \\
\hline L2 Pisella & 2838 & $46^{\circ} 26^{\prime} 28.62^{\prime \prime}$ & $10^{\circ} 32^{\prime} 35.90^{\prime \prime}$ & 0.0015 & 0.193 & - & - & - \\
\hline Bianco & 2609 & $46^{\circ} 20^{\prime} 40.83^{\prime \prime}$ & $10^{\circ} 29^{\prime} 32.31^{\prime \prime}$ & 0.0434 & 1.918 & 0.02 & 73 & 24 \\
\hline Nero & 2388 & $46^{\circ} 20^{\prime} 09.14^{\prime \prime}$ & $10^{\circ} 28^{\prime} 52.76^{\prime \prime}$ & 0.0779 & 1.949 & - & 64 & 32 \\
\hline
\end{tabular}

Lat, latitude; Long, longitude. 
performed, including specific laboratory intercomparisons for low concentration samples (Escudero-Oñate, 2017).

The sampling procedures for macroinvertebrates followed the standardized protocol developed during previous projects (NIVA, 1987; ICP Waters Programme Centre, 1996, 2010; Boggero et al., 2011). Macroinvertebrates were sampled using a handle-net (250 $\mu \mathrm{m}$ mesh aperture) in the littorals, at a maximum depth of $0.5 \mathrm{~m}$, to obtain semi-quantitative samples. In each lake, the habitats present (mud, gravel, cobbles, pebbles or rocks), known to control macroinvertebrate abundance and distribution (Abraham et al., 1999; Jyväsjärvi et al., 2013), were closely examined by dragging the substrate over a length of $1 \mathrm{~m}$. Three replicates, representative of the peculiar habitats of each lake, were taken. Samples were sorted into major groups of macroinvertebrates using a stereo-microscope (Leica M125, magnification 80x), and preserved in $80 \%$ ethanol for subsequent taxonomic identification. Most of the groups were identified to species level by preparing slides of sexually mature Oligochaetes, and of larvae, pupae or pupal exuviae (when present) of Chironomids. Slides were observed under a Zeiss Axiolab microscope (1000x). Genus or family level of identification was preferred when poor conservation status of specimens (due to damages caused by friction) or the presence of juveniles did not allow the identification to species level. Relative abundances (\%) were then estimated. The identification envisaged the use of specific taxonomic keys: Timm (2009) and Schmelz and Collado (2010) for the oligochaetes; Wiederholm $(1983,1986)$ for the Chironomids and several guides with national distribution related to the remaining groups of macroinvertebrates (AA.VV., 1977-1985).

Epilithic diatoms were sampled on cobbles of appropriate size (mesolithal), preferably free of filamentous algae. At least 5 cobbles were collected from the littoral zone of each lake, far from inflow influence. The top surface of each cobble was brushed with a clean toothbrush to remove the biofilm (Kelly et al., 1998; CEN, 2003). In laboratory, the samples were then treated with hot hydrogen peroxide and hydrochloric acid following standard procedures (Battarbee et al., 2001), and finally mounted using Naphrax on permanent slides for species identification (Zeiss Axiolab, magnification $1000 \mathrm{x})$. The taxonomic recognition was based on Krammer and Lange-Bertalot (1986-1991), Krammer (2000). The most recent nomenclature was updated following Cantonati et al. (2017) and using the software OMNIDIA version 6.0.1 (2016) (Lecointe et al., 1993). For each sample, a minimum of 300 valves were identified and results were expressed as relative abundances (\%) (Battarbee, 1986; Battarbee et al., 2001).

In summary, the sampling procedure includes a total of 72 samples: 8 samples for chemical analysis (1 per lake), 3 replicate samples for each lake to determine the structure of the macroinvertebrate assemblage, and 5 replicates for each lake for diatom composition studies.

\section{Data analysis}

A Hierarchical Cluster Analysis (HCA; Rokach and Maimon, 2005) was first applied to chemical data to identify the main sources of variation within the lake waters. Ward's minimum variance method was used as a standard clustering procedure and Euclidean distance was used as a distance measure.

Before running a Canonical Correspondence Analysis (CCA), a Monte-Carlo permutation test (Hope, 1968) calculated by randomly sampling 999 permutations under a reduced model had been carried out to estimate the significance of each single parameter and exclude closely related variables. Then, a CCA (CANOCO 4.5 programme; ter Braak and Šmilauer, 2002) was selected to analyze the distribution of diatoms and macroinvertebrates in relation to abiotic factors (lake geographical and morphological features, water chemistry). Macroinvertebrates and diatoms presence, expressed as relative abundances, underwent square root transformation to downweight rare species. Very rare species, those present with relative abundances lower than $3 \%$, were not included in the data set to avoid noise effect (Gauch, 1982). All the environmental variables (except $\mathrm{pH}$ ) were log-converted to transform skewed data to approximately conform to normality (Box and Cox, 1964). The combined effort of both techniques (HCA and CCA) enabled to obtain more robust interpretations of the variability in lake water chemistry and of its interaction on the community assemblages.

Then, the most well-known diversity, abundance of taxa, and evenness indices were evaluated. Richness (evaluated as number of taxa per each lake), two different diversity indices (Shannon-Weaver and Simpson) (Shannon and Weaver, 1948; Simpson, 1949), and evenness (Pielou, 1966) were applied to macroinvertebrates and diatoms. The goal was to highlight differences among lakes as regard their environmental status, how indirect anthropogenic pressures impact both communities, and to test whether the results obtained from these indices were comparable while explaining lakes' assemblages. Thus, a regression analysis (RA; Chatterjee et al., 2000) was performed for estimating the relationships among the main key drivers of assemblage structure highlighted by the CCA, and the biodiversity indices. In this case, richness was logtransformed to improve the assumption of normality.

Finally, the non-parametric Kruskal-Wallis test (Kruskal and Wallis, 1952) was performed on two different sets of lakes: R Alps, sampled during the present study, and Pennine-Lepontine lakes (P-L Alps). The data 
of P-L Alps, sampled following the same protocols, belongs to an extensive survey performed within EU projects on mountain lakes (Marchetto et al., 2009; Rogora et al., 2013). Kruskal-Wallis test aimed to assess whether median distributions confirm a separation or indicate a homogeneity between the two lake data sets. The test was performed both on the main chemical variables and on the different biodiversity indices applied to macroinvertebrates and diatoms.

\section{RESULTS}

\section{Water chemistry}

The main chemical features of the 8 lakes considered in this study are shown in Tab. 2. The lakes were characterized by a high variability of solute content, spanning from very dilute (e.g. conductivity below $10 \mu \mathrm{S}$ $\mathrm{cm}^{-1}$ at $20^{\circ} \mathrm{C}$ ) to mineralized waters (above $200 \mu \mathrm{S} \mathrm{cm}^{-1}$ ). The prevailing ions in most of the lakes were calcium, among cations, and bicarbonates, among anions; however, these ions were present in different concentrations in the different lakes analyzed. For instance, calcium ranged from $27 \mu \mathrm{eq} \mathrm{L}^{-1}$ to more than $1000 \mu \mathrm{eq} \mathrm{L}^{-1}$. Sulphate also showed a wide variability in concentrations, from values below $100 \mu \mathrm{eq} \mathrm{L} \mathrm{L}^{-1}$ to $1700-1800 \mu \mathrm{eq} \mathrm{L} \mathrm{L}^{-1}$. SNP lakes are differently sensitive to acidification, as shown by $\mathrm{pH}$ and alkalinity values: $\mathrm{pH}$ varied from 6.2 to 8.0 , and alkalinity from $20 \mu \mathrm{eq} \mathrm{L}^{-1}$ to more than $500 \mu \mathrm{eq} \mathrm{L}^{-1}$. In particular, Lake Rosole differed from the other sites for its very low ionic content and conductivity, and its low buffer capacity (low $\mathrm{pH}$ and alkalinity values). This lake also differed for nutrient concentrations: phosphorous was higher than the other lakes (6 and $15 \mu \mathrm{g} \mathrm{P} \mathrm{L}^{-1}$ as reactive and total phosphorous, respectively), while silica was lower $(0.10$

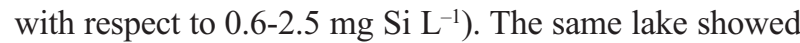
higher TOC concentrations $\left(1.67 \mathrm{mg} \mathrm{C} \mathrm{L}^{-1}\right.$ compared to 0.1-0.7 $\mathrm{mg} \mathrm{C} \mathrm{L}^{-1}$ in the other lakes); nitrogen also was mainly present in organic form (more than $80 \%$ of total nitrogen) in this lake, indicating a higher organic matter content (Tab. 2).

Due to TP concentrations below $4 \mu \mathrm{g} \mathrm{P} \mathrm{L} \mathrm{L}^{-1}$, the remaining lakes can be classified as ultra-oligotrophic. The only exception was L2 Pisella, showing a slightly higher phosphorous content $\left(\mathrm{TP}=7 \mu \mathrm{g} \mathrm{P} \mathrm{L}^{-1}\right)$. Total nitrogen and TOC concentrations were very low, with values of $<0.50$ $\mathrm{mg} \mathrm{N} \mathrm{L}^{-1}$ for $\mathrm{TN}$, and between 0.10 and $0.70 \mathrm{mg} \mathrm{C} \mathrm{L}^{-1}$ for TOC. Nitrate was the dominant form of nitrogen in the lake waters, representing more than $80 \%$ of the total nitrogen content. Nitrate concentrations varied from negligible values (below the detection limit of the method used) to 15 $20 \mu \mathrm{eq} \mathrm{L}{ }^{-1}$ (Tab. 2).

Chemical data highlighted the high heterogeneity characterizing even lakes located in a limited geographical area: as an example, the two lakes in the Pisella Valley showed different ionic contents, with major ions concentrations being one order of magnitude higher in L1 than in L2. A similar condition was found in the Rosole Valley (e.g. L1 Rosole and P1 Rosole).

The comparison of $\mathrm{R}$ and P-L Alps lakes (Fig. 2)

Tab. 2. Chemical composition of the lakes considered in this study and referred to the summer sampling 2011.

\begin{tabular}{|c|c|c|c|c|c|c|c|c|c|}
\hline Variable & Unit & Rosole & Manzina & P1 Rosole & L1 Rosole & L1 Pisella & L2 Pisella & Bianco & Nero \\
\hline $\mathrm{pH}$ & & 6.15 & 7.78 & 7.37 & 6.84 & 8.00 & 7.36 & 7.57 & 7.19 \\
\hline Cond. & $\mu \mathrm{S} \mathrm{cm}-1$ & 8 & 170 & 26 & 197 & 222 & 27 & 73 & 29 \\
\hline Alk. & meq $\mathrm{L}^{-1}$ & 0.02 & 0.55 & 0.11 & 0.09 & 0.55 & 0.13 & 0.26 & 0.12 \\
\hline $\mathrm{Cl}$ & $\mathrm{mg} \mathrm{l}^{-1}$ & 0.11 & 0.06 & 0.12 & 0.14 & 0.15 & 0.09 & 0.09 & 0.34 \\
\hline $\mathrm{SO}_{4}$ & $\mathrm{mg} \mathrm{l}^{-1}$ & 1.64 & 57.20 & 5.26 & 88.10 & 85.20 & 5.16 & 20.00 & 6.24 \\
\hline $\mathrm{N}^{-\mathrm{NO}_{3}}$ & $\mu \mathrm{g} \mathrm{1^{-1 }}$ & 0 & 228 & 90 & 264 & 198 & 93 & 157 & 97 \\
\hline $\mathrm{N} \mathrm{NH}_{4}$ & $\mu \mathrm{g} \mathrm{1^{-1 }}$ & 35 & 2 & 17 & 7 & 8 & 6 & 3 & 7 \\
\hline $\mathrm{Ca}$ & $\mathrm{mg} \mathrm{l}^{-1}$ & 0.54 & 18.30 & 2.91 & 21.00 & 21.70 & 3.69 & 7.09 & 3.38 \\
\hline $\mathrm{Mg}$ & $\mathrm{mg} \mathrm{l}^{-1}$ & 0.11 & 9.90 & 0.66 & 10.50 & 14.90 & 0.51 & 3.04 & 0.71 \\
\hline $\mathrm{Na}$ & $\mathrm{mg} \mathrm{l}^{-1}$ & 0.05 & 0.61 & 0.22 & 1.27 & 0.57 & 0.23 & 0.68 & 0.61 \\
\hline $\mathrm{K}$ & $\mathrm{mg} \mathrm{l}^{-1}$ & 0.53 & 0.34 & 0.24 & 0.44 & 0.16 & 0.12 & 1.15 & 0.37 \\
\hline $\mathrm{RP}$ & $\mu \mathrm{g} \mathrm{l^{-1 }}$ & 6 & 3 & 1 & 0 & 2 & 3 & 1 & 2 \\
\hline $\mathrm{TP}$ & $\mu \mathrm{g} \mathrm{1^{-1 }}$ & 15 & 3 & 4 & 1 & 4 & 7 & 2 & 3 \\
\hline $\mathrm{TN}$ & $\mathrm{mg} \mathrm{l}^{-1}$ & 0.21 & 0.22 & 0.12 & 0.26 & 0.21 & 0.11 & 0.17 & 0.13 \\
\hline $\mathrm{RSi}$ & $\mathrm{mg} \mathrm{l}^{-1}$ & 0.10 & 0.72 & 0.67 & 2.46 & 0.72 & 0.74 & 0.84 & 0.64 \\
\hline TOC & $\mathrm{mg} \mathrm{l}^{-1}$ & 1.67 & 0.11 & 0.30 & 0.17 & 0.34 & 0.32 & 0.24 & 0.67 \\
\hline
\end{tabular}

Cond, conductivity at $20^{\circ} \mathrm{C}$; Alk, alkalinity; RP, reactive phosphorus; TP, total phosphorus; TN, total nitrogen; $R S i$, reactive silica; TOC, total organic carbon. 
showed that, despite the low number of lakes considered in this study ( $\mathrm{n}=8)$, the R Alps lakes had a higher and more variable solute content, especially as regards sulphate and base cations. These lakes were also characterized by higher $\mathrm{pH}$ and alkalinity values compared to the lakes in the P-L Alps (Marchetto et al., 2009; Rogora et al., 2013). This indicates a lower sensitivity of R Alps to acidification and a higher buffer capacity of lake waters. $\mathrm{NO}_{3}$ concentrations in R Alps lakes were lower than those of other lakes in remote areas (Rogora et al., 2008), but comparable to those of lakes in the P-L Alps (Fig. 2), indicating a similar contribution from atmospheric deposition which is the main source of inorganic $\mathrm{N}$ to these high altitude lakes.

According to the HCA, two main groups were identified (Fig. 3), the first including lakes Manzina, L1 Rosole and L1 Pisella, the second the remaining lakes (Rosole, P1 Rosole, L2 Pisella, Bianco and Nero). Despite they belong to the same valley, L1 Pisella and L2 Pisella were grouped into different clusters, and the same occurred to L1 Rosole and P1 Rosole.

\section{Assemblage structure of macroinvertebrates}

As a whole, 2927 individuals were collected along lake shorelines, belonging to 32 taxa considering family, genus, and species level of identification. The taxa recorded in each lake are summarized in Supplementary Material 1.

Dominant groups were oligochaetes and chironomids, variously represented in each lake. Their populations cover over $97 \%$ of the macroinvertebrate assemblages. The abundances of Coleoptera (1.1\%) and Trichoptera $(0.9 \%)$ were significantly lower. Mollusca (Bivalvia), and other Diptera families (Sciaridae, Tipulidae) were very rare $(<0.7 \%)$.

Based on the mean number of individuals (Supplementary Material 1), the most abundant chironomid species were Paratanytarsus austriacus and Micropsectra radialis, followed by Paracladius alpicola. Within oligochaetes, Enchytraeidae, mainly belonging to the semiaquatic genus Cognettia, prevail in these ecosystems. Nais communis and Tubificidae (probably Tubifex tubifex) were numerous, but only in lakes Bianco and Rosole. Coleoptera Dytiscidae abounded only in Lake Rosole, while bivalves had a few representatives in Lake Bianco.

As for the number of species, Clitellates were represented by 5 species of Naididae (of which 4 Naidinae and 1 Tubificinae), 5 of Enchytraeidae, and 1 of Lumbriculidae, while chironomids by 2 species of Diamesinae, 8 of Orthocladinae, and 4 of Chironominae. The remaining taxonomic groups (like Diptera other than
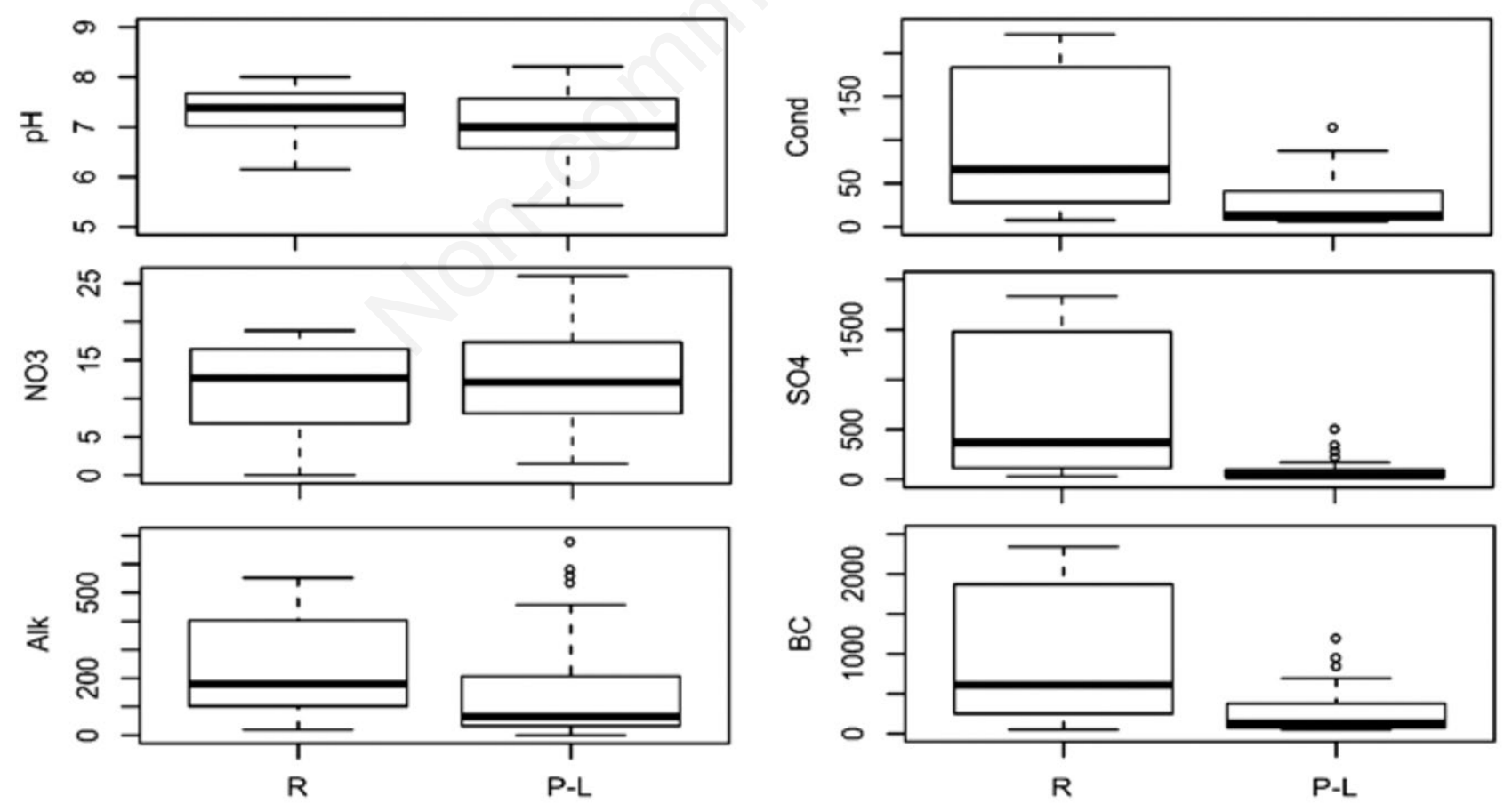

Fig. 2. Kruskal Wallis test box-and-whisker plots of selected chemical variables of Rhaetian Alps (R Alps) lakes vs a survey lakes' group in the Pennine-Lepontine Alps (P-L Alps). Boxes display median, first and third quartiles, minimum and maximum values. $\mathrm{R}$ Alps ( $\mathrm{n}=8)$, P-L Alps $(\mathrm{n}=53)$. Cond, conductivity in $\mu \mathrm{S} \mathrm{cm}-1$ at $20^{\circ} \mathrm{C}$; Alk, alkalinity in $\mu \mathrm{eq} \mathrm{L}^{-1}$; $\mathrm{BC}$, sum of base cations $(\mathrm{Ca}, \mathrm{Mg}, \mathrm{Na}$, $\mathrm{K}) \mathrm{NO}_{3}$ and $\mathrm{SO}_{4}$ concentrations in $\mu$ eq $\mathrm{L}^{-1}$. 
chironomids, and Bivalvia) were represented by a single family and by a single species.

$\mathrm{R}$ Alps lakes were also characterized by a high variability in term of species richness. Lakes P1 Rosole, L1 Rosole, L1 Pisella, and Nero had a lower number of taxa $(\leq 6)$, while the remaining lakes displayed a richness two times higher. Diversity indices (Tab. 3) showed that four lakes had Shannon diversity higher than 1 (Bianco, Manzina, L2 Pisella, Rosole), in accordance to the high species richness detected, Simpson index $<0.4$, and Pielou evenness $>0.5$. The remaining lakes ( $\mathrm{P} 1$ Rosole, L1 Rosole, L1 Pisella, and Nero) had very low species richness $(\leq 6)$, thus their diversity indices exhibited values lower than 1, and Pielou evenness $<0.5$ (for Lake L1 Pisella $<0.2$ ).

\section{Assemblage structure of diatoms}

A total of 111 taxa belonging to 38 genera were identified to the highest taxonomic resolution, mostly to species level, and, when possible, to sub-species. Eightynine out of $111(80 \%)$ were present with abundances lower than 3\%. Thirty-three (29\%) were categorized as taxa with current trend "decreasing", following the Threat criteria and categories of the German Red List for Central Europe (Lange-Bertalot, 1996; Ludwig et al., 2009). The species list and their codes are available in Supplementary Material 2.

The most taxa-rich groups were the naviculoid biraphids (19 species) and the monoraphid (15 species). The naviculoids comprised 9 genera (number of species in parenthesis): Navicula (7), Microcostatus (3), Craticula (2), Sellaphora (2), Cavinula (1), Adlafia (1), Eolimna (1), Diadesmis (1), and Luticola (1). The monoraphids included 6 genera: Psammothidium (9), Achnanthidium (2), Achnanthes (1), Karayevia (1), Eucocconeis (1), and Rossithidium (1). Other biraphids included Nitzschia, Pinnularia, and 10 cymbelloid taxa belonging to 5 genera: Cymbella (3), Encyonema (3), Encyonopsis (2), Delicata (1), and Navicymbula (1). Other taxa-rich groups were the fragilarioids (12 species), with the genera Fragilaria (5), Staurosira (3), Pseudostaurosira (3), and Staurosirella (1).

The most common and abundant species were Achnanthidium minutissimum, Encyonema minutum, and Cymbella affinis, followed by Nitzschia elegantula and Achnanthidium helveticum, also common, but reaching high percentages only in a few lakes (the former in Lake L1 Rosole 19.9\%, and the latter in lakes P1 Rosole 17.2\% and L1 Rosole 9.9\%). Noteworthy the presence in Lake Rosole of Microcostatus krasskei with high abundances (39\%) occurring usually on lithic pseudo-aerial substrates; and of the rheophilic Fragilaria gracilis, recorded with high values only in Lake Nero (83\%).

Diversity indices showed marked differences in richness and evenness among SNP lakes (Tab. 4). Lake
Nero had the lowest richness, Shannon diversity and Pielou evenness. In Lake Rosole, the pattern was opposite, with high values for richness, Shannon index, and Pielou evenness, while a very low Simpson index. The other lakes showed Pielou evenness $>0.6$, Simpson index $<0.3$,

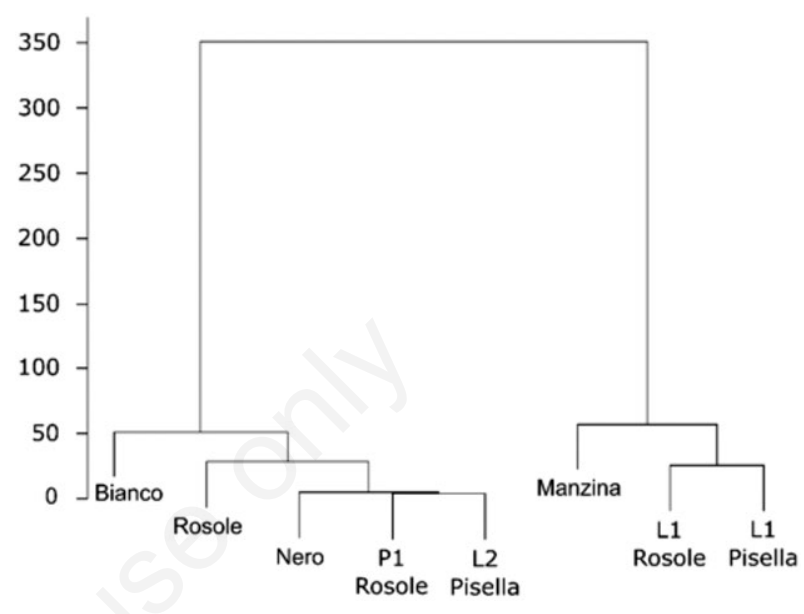

Fig. 3. Hierarchical cluster analysis plot for lakes based on chemical variables. Proximity measure: squared Euclidean distance. Clustering method: Ward.

Tab. 3. Richness, Shannon and Simpson diversity, and Pielou evenness indices applied to macroinvertebrates in the lakes studied.

\begin{tabular}{lcccc} 
Lake & Richness & Shannon & Simpson & Pielou \\
Rosole & 14 & 1.37 & 0.37 & 0.62 \\
\hline Manzina & 11 & 1.75 & 0.21 & 0.73 \\
\hline P1 Rosole & 5 & 0.71 & 0.68 & 0.44 \\
\hline L1 Rosole & 5 & 0.74 & 0.66 & 0.46 \\
\hline L1 Pisella & 5 & 0.30 & 0.87 & 0.17 \\
\hline L2 Pisella & 12 & 1.39 & 0.38 & 0.56 \\
\hline Bianco & 13 & 1.83 & 0.21 & 0.71 \\
\hline Nero & 6 & 0.58 & 0.75 & 0.33
\end{tabular}

Tab. 4. Richness, Shannon and Simpson diversity, and Pielou evenness indices applied to diatoms in the lakes studied.

\begin{tabular}{lcccc} 
Lake & Richness & Shannon & Simpson & Pielou \\
Rosole & 25 & 2.29 & 0.19 & 0.71 \\
\hline Manzina & 30 & 2.08 & 0.21 & 0.61 \\
\hline P1 Rosole & 30 & 2.12 & 0.24 & 0.62 \\
\hline L1 Rosole & 28 & 2.69 & 0.10 & 0.81 \\
\hline L1 Pisella & 16 & 1.66 & 0.28 & 0.60 \\
\hline L2 Pisella & 14 & 1.53 & 0.28 & 0.58 \\
\hline Bianco & 39 & 2.38 & 0.16 & 0.65 \\
\hline Nero & 10 & 0.64 & 0.73 & 0.28
\end{tabular}


and Shannon index $>2$, except for lakes L1 Pisella and L2 Pisella, where richness values were the half of the previous ones.

\section{Relation between abiotic factors and macroinvertebrate-diatom assemblages}

The Monte-Carlo permutation test was performed on a set of 22 environmental variables characterizing the chemical composition of lake waters, the lakemorphology and the geographical distribution of the lakes. It retained 14 variables for the subsequent analyses $(\mathrm{pH}$, sulphate, calcium, magnesium, sodium, potassium, TP, $\mathrm{TN}$, reactive silica, TOC, altitude, lake area, catchment area, $\%$ glacier cover). The test excluded temperature (related to altitude), alkalinity (related to $\mathrm{pH}$ ), conductivity (related to major ion concentrations), nitrate (related to TN), RP (related to TP), and ammonium and chloride for their very low values.

CCA, applied to R Alps lakes, accounted for $92 \%$ of the total variance (the first axis representing $51 \%$ of the total variance and the second axis a further $41 \%$ ). CCA revealed two outliers, lakes Nero and L1 Pisella, characterized by high relative abundances of two diatom species (85\% Fragilaria gracilis and $42 \%$ Encyonopsis microcephala).
From the analysis, two groups of lakes were selected, reflecting their geographical position and water chemical composition (Fig. 4). The first group, on the right side of the graph, represents the lower altitude, larger lake and basin areas (i.e. lakes Nero and Bianco), and with higher nutrient content (relatively higher TOC and TP - lakes Rosole, L2 Pisella, Nero). The second group, on the left side of the graph, consisted of lakes of higher altitude, smaller in lake and basin areas (i.e. lakes P1 Rosole, L1 Rosole, L1 Pisella), and with higher solute content and pH (lakes Manzina, L1 Rosole, L1 Pisella). The same two groups separate also the warmer lakes, characterized by stronger water level fluctuation (WLF - right side) due to the absence of an inlet or to high variations in water inputs, from the colder ones, with scarce evidence of WLF (left side).

Benthic macroinvertebrate taxa appeared to reflect differences in lake types and climatic conditions (Fig. 4 left), with Naididae, Lumbriculidae, Orthocladiinae, and Tanytarsini (represented by Micropsectra radialis) present in the lower and larger lakes, where altitude determines warmer water conditions. On the contrary, Trichoptera, Diamesinae, Tanytarsini (on this occasion represented by Paratanytarsus austriacus), and Coleoptera Dytiscidae dominated the higher and smaller lakes, where altitude
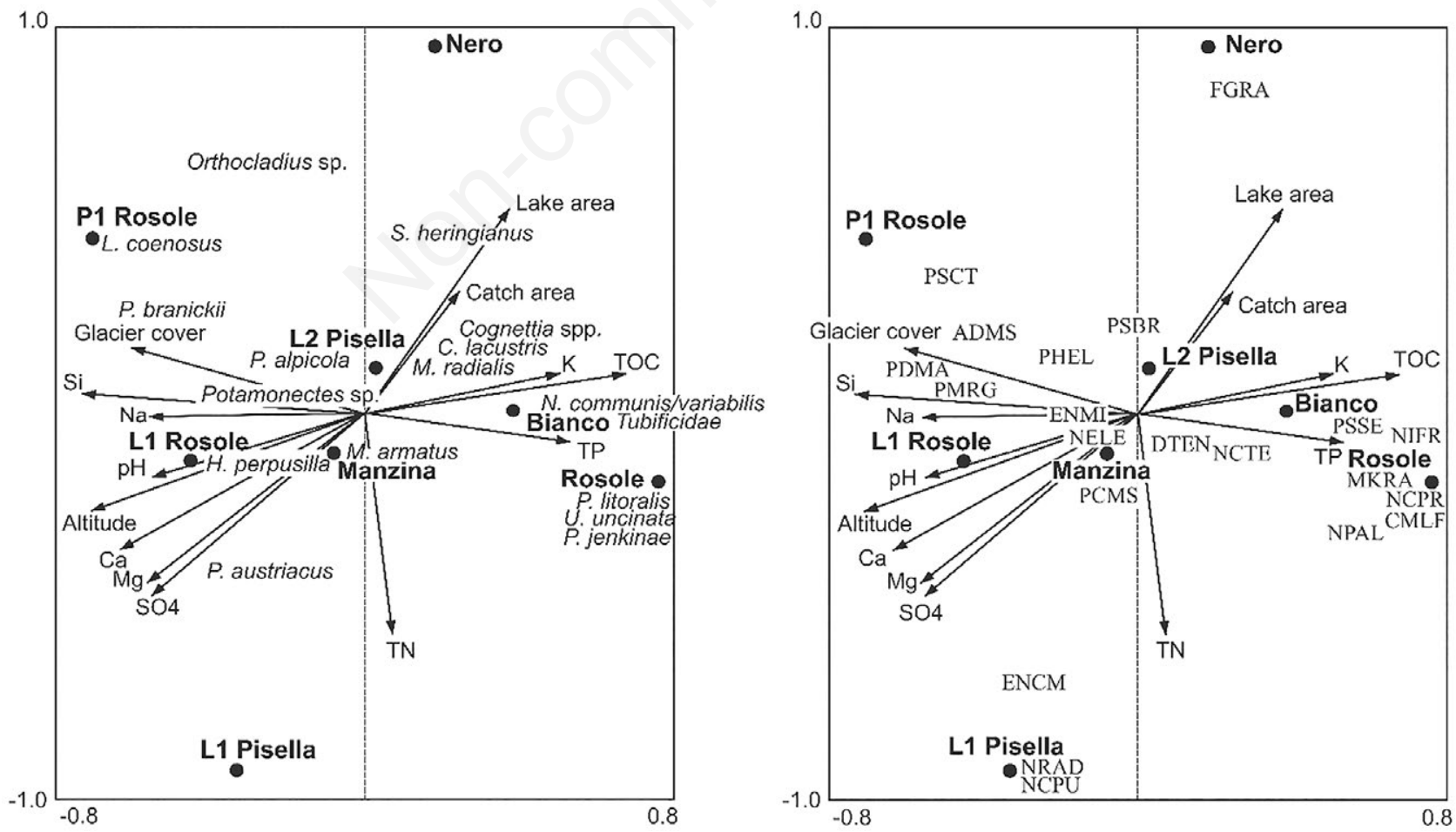

Fig. 4. CCA applied to environmental features and biotic lake representatives (macroinvertebrates-left, diatoms-right). $\bullet$, lakes. Codes for diatoms are available in Supplementary Material 2. 
determines colder local conditions. The genus Cognettia represented the only exception, being more abundant in the lower and larger lakes, but also present in higher altitude lakes.

Diatoms distribution among lakes (Fig. 4 right) was mainly related to nutrient concentration and total ionic content of the lakes, thus taxa were not grouped on a geographical or a morphological basis.

After performing the RA among the different indices applied to macroinvertebrates $v s$ altitude and $\mathrm{pH}$ (Fig. 5), highlighted by the CCA as the main drivers characterizing the macroinvertebrate assemblages, significant relationships with different and decreasing level of significance were obtained. Altitude vs: i) the logtransformed richness, the Shannon and the Simpson diversity indices at a significance of $\mathrm{P}=0.001$ (Fig. $5 \mathrm{a}-\mathrm{c}$ ), and $v s$ ii) the Pielou index at $\mathrm{P}=0.01$ (Fig. $5 \mathrm{~d}$ ). In the case of $\mathrm{pH}$, no significant relationship was found both $v s$ i) the log-transformed richness, the Shannon and the Simpson diversity indices $(\mathrm{P}>0.5)$ (Fig. $5 \mathrm{a}-\mathrm{c})$, and $v s$ ii) the Pielou index $(\mathrm{P}=0.1)$ (Fig. 5d).

The same analysis ran considering the different indices applied to diatoms and $\mathrm{pH}$ (main driver influencing diatom assemblages' structure according to the CCA) pointed out that the relationships with the logtransformed richness, the Shannon and the Simpson diversity indices and the Pielou evenness were not significant (Fig. 5). In the case of diatoms, the biodiversity indices were neither influenced by altitude nor by $\mathrm{pH}$.

A comparison between biodiversity indices applied to R Alps lakes and to a larger dataset of lakes belonging to the P-L Alps was performed through Kruskal Wallis test (Fig. 6). The results indicated that macroinvertebrates biodiversity indices were lower in the R Alps than in the P-L Alps, with different degree of significance. On the contrary, the results of the same test applied to diatoms were not statistically significant.

\section{DISCUSSION}

The chemical characteristics of the lakes in the R Alps reveal a wide spatial heterogeneity, characterizing even lakes in the same valley, or however placed in a limited geographical area. The groups of lakes resulting from the CA are not dependent on geographical attributes but on the ionic content of each lake, mainly represented by calcium and sulphate (Fig. 3; Tab. 2).

A high heterogeneity in the lithological composition of the bedrock can probably be the main factor responsible for the wide range of chemical characteristics detected and, in particular, for major ion concentrations (Marchetto et al., 1995). Even small differences in the mineral composition of rocks and soils in the catchments may indeed explain the different lake chemistry, especially when more weatherable minerals are present (Kamenik et al., 2001). Lakes in the R Alps are characterized by higher $\mathrm{pH}$ and alkalinity than lakes in the P-LAlps, indicating a lower sensitivity to acidification and a higher buffer capacity of their waters.

A further factor affecting lake chemical composition, especially trophic level and organic matter content, is the presence of anthropogenic activities determining the nutrient enrichment of the lakes (Tiberti et al., 2014). The presence of a refuge and of livestock in the summer period may explain the higher nutrient and organic matter content in Lake Rosole compared to the other lakes. As regard nitrogen content, lakes in the $\mathrm{R}$ Alps are characterized by average $\mathrm{NO}_{3}$ concentrations comparable to those found in other high altitude lakes in the P-L Alps $\left(15-20 \mu \mathrm{eq} \mathrm{L}^{-1}\right)$. This indicates a contribution from medium- or long-range atmospheric transport and deposition of $\mathrm{N}$ compounds (Rogora et al., 2008), representing the main source of inorganic $\mathrm{N}$ to these high altitude lakes. A study performed on sediments of lakes in the R Alps reveals a slight contamination by persistent organic pollutants (Poma et al., 2017); however, it also confirms the role of medium-range atmospheric transport in the transfer of POPs or other atmospheric compounds to these lakes.

In high altitude lakes, the macroinvertebrate assemblages are directly related with lithological and chemical conditions but, interestingly, chironomids, are mainly influenced by the altitudinal/temperature gradient (Fjellheim et al., 2000, 2009, Marziali and Rossaro, 2013).

Our findings through CCA applied to environmental features and macroinvertebrates seem to mirror differences in lake types, determined by lake area and geographical position (influencing water level fluctuations), and nutrient concentrations. These assemblages are indeed characteristic of oligotrophic waters and usually similar among lakes, but local differences due to lake sun-exposure, land use, and water turbidity may vary their composition. In general, the lakes studied are characterized by cold-adapted species of oligochaetes typical of the Paleartic region, like Cognettia spp. and Stylodrilus heringianus.

Some of the species found at these altitudes strictly represent the lake environment they inhabit, being adapted to temperatures lower than $10^{\circ} \mathrm{C}$ (Rossaro, 1991; Marziali and Rossaro, 2013) or to altitudes higher than 1800-2000 (Boggero et al., 2006; Hamerlik et al., 2017; Boggero, 2018). This is the case of: Pseudodiamesa branickii and $P$. nivosa, Corynoneura lacustris, Paratanytarsus austriacus, Paracladius alpicola, Micropsectra radialis, Tanytarsus lugens among chironomids. By contrast, some others are peculiar of lower altitude lakes (Naididae and Tubifex tubifex), raised bogs (Limnephilus coenosus, Trichoptera), 

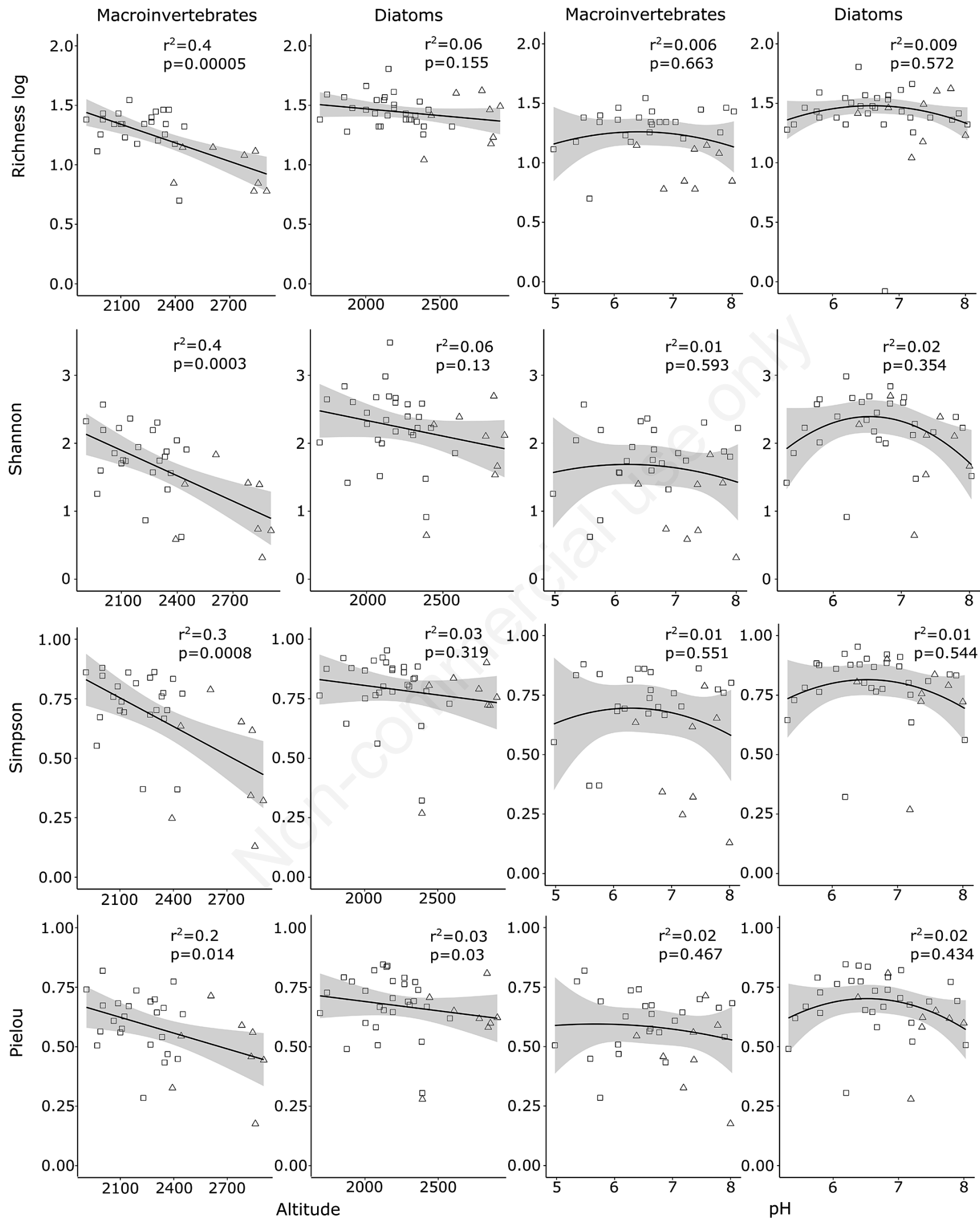

Fig. 5. RA applied to altitude and $\mathrm{pH}$ and community assemblages of macroinvertebrates-left, and diatoms-right. $\square$, P-L Alps; $\Delta, \mathrm{R}$ Alps lakes. 
terrestrial and semiterrestrial habitats (Camptocladius stercorarius - chironomids - preferring farm manure present near Lake Nero, and Limnophyes sp. typical of wet soils and flooded grassland). In particular, Naidinae, exclusive of lakes Rosole and Bianco, are generally widespread in lakes with vegetation, moss and algae on hard substrates (Dumnicka, 1994). Among them, remarkable is the presence of Paranais litoralis and of
Chironomus cingulatus (Lake Rosole), euryhaline species confined to muddy substrata and able to withstand considerable variations in salinity (Brinkhurst and Jamieson, 1971; Grigelis, 1980; Moller Pillot, 2009). Their presence suggests water salinity variations related to temperature rises and strong evapo-transpiration, causing solute increases during summer. The presence in the same lake of Pristina (P.) jenkinae (formerly, Pristinella idrensis)
Macroinvertebrates
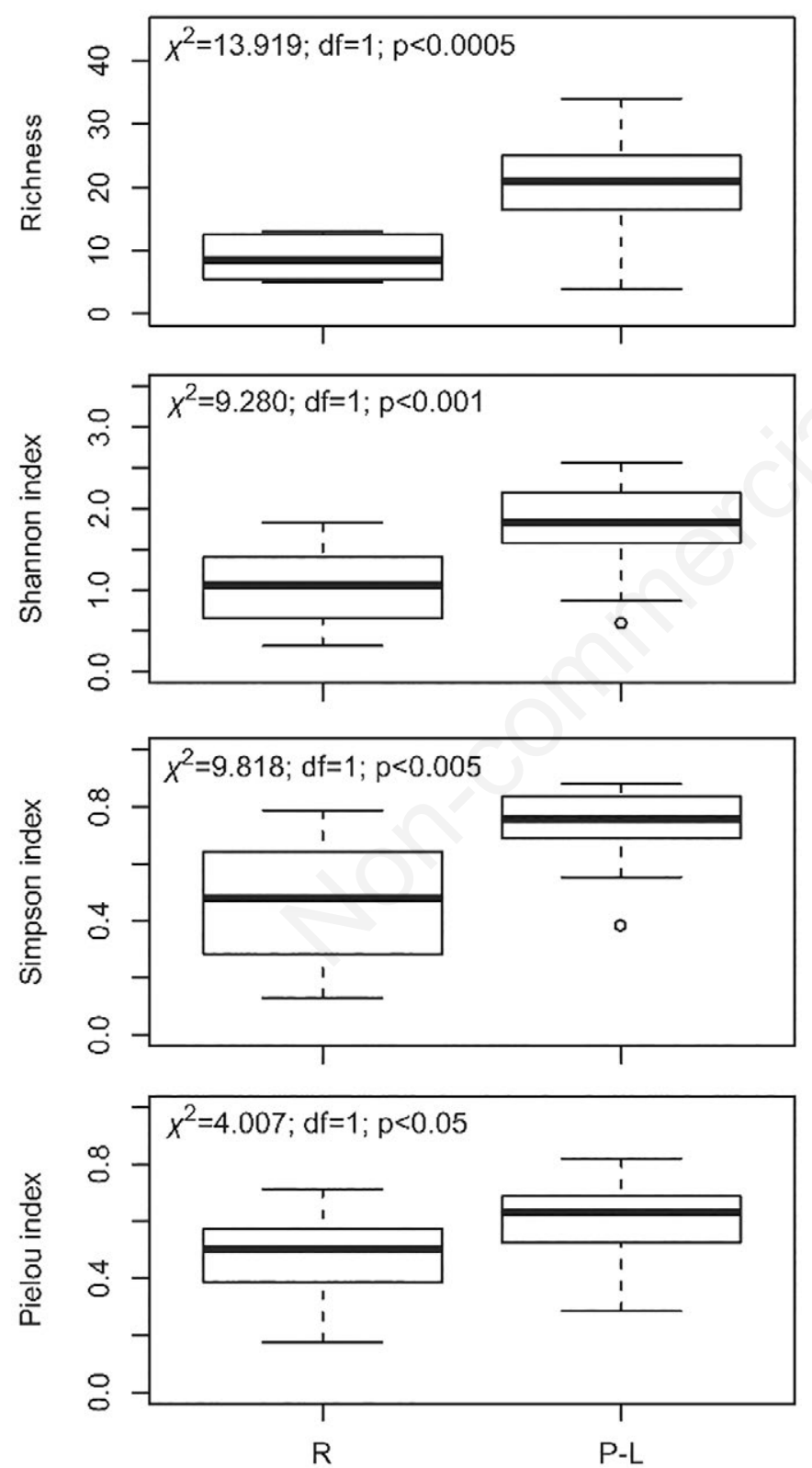

Diatoms
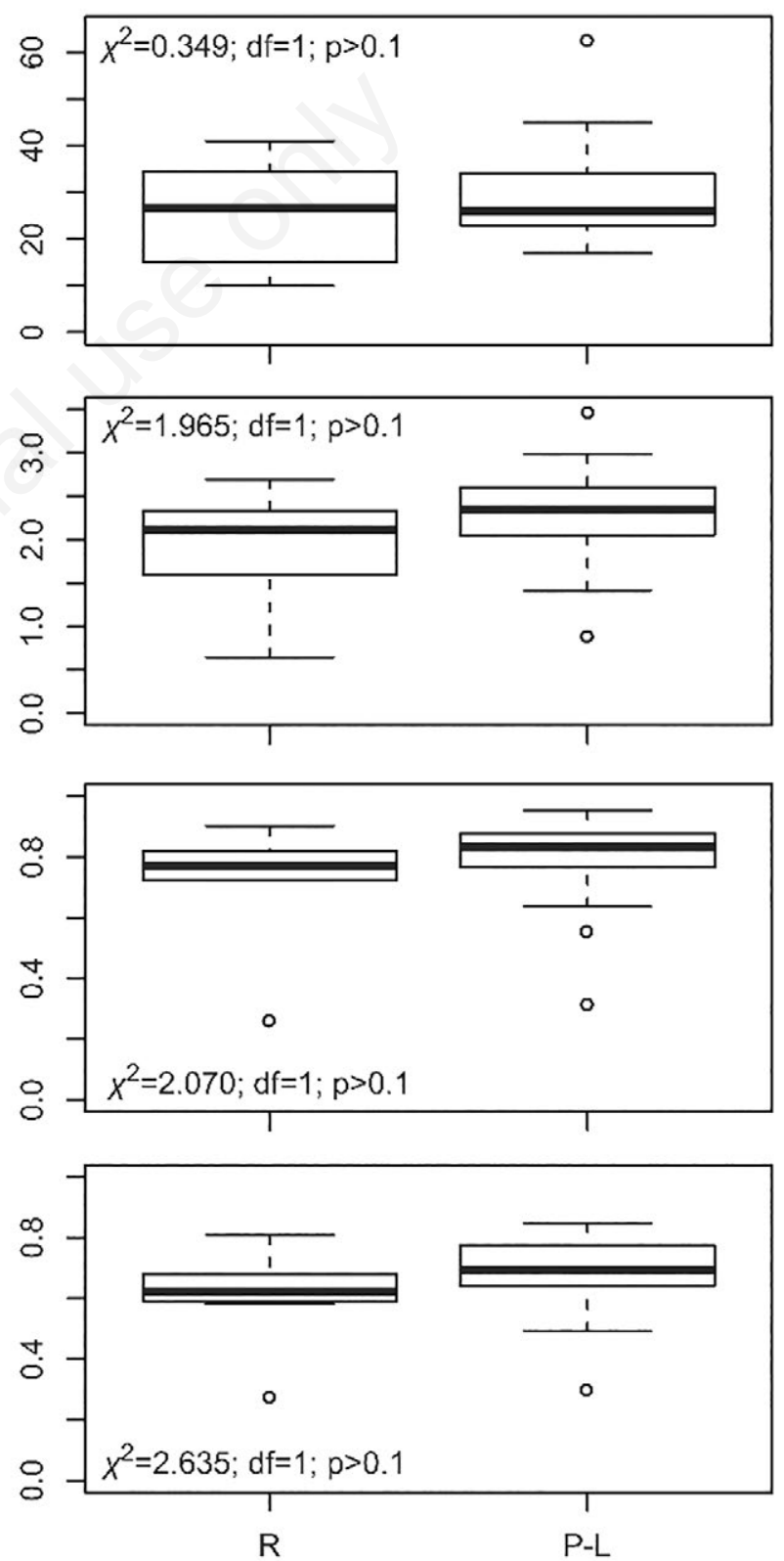

Fig. 6. Kruskal Wallis test box-and-whisker plots of the biodiversity indices applied to macroinvertebrates and diatoms of Rhaetian Alps lakes (R Alps) vs a survey lakes' group in the Pennine-Lepontine Alps (P-L Alps). Boxes display median, first and third quartiles, minimum and maximum values. R Alps ( $\mathrm{n}=8$ ), P-L Alps (macroinvertebrates $\mathrm{n}=24$, diatoms $\mathrm{n}=29$ ). 
and Uncinais uncinata may indicates higher water temperature, and presence of submerged vegetation. Genera like Heleniella, Orthocladius, and Tvetenia, typical of flowing waters, are probably related to the proximity of inlets/outlets. On the contrary, in Lake Rosole, the presence of Paratrichocladius, typical of cool and still waters, but also of flowing and brackish waters, can be related to water salinity variations like Pristina (P.) jenkinae.

In the Alps, the altitudinal/temperature gradient is of particular interest for the distribution of flying insects (de Mendoza and Catalan, 2010), contributing to their dominance at the highest elevations because of their freezing-tolerance (Bale et al., 2002) (Fig. 7). Thus, while chironomids tend to decrease from the higher to the lower altitude lakes, an opposite trend is observed for oligochaetes. We assume that this shift can be related to temperatures mitigation together with a concomitant enrichment in organic matter as the altitude decreases, causing a consequent change in the macroinvertebrate assemblages, from the early formation of lakes by glaciation, up to the present days (lake ontogeny hypothesis).

The R Alps lakes we considered are indeed higher in elevation (2400-2900 m asl) compared to the PennineLepontine Alps (1881-2450 $\mathrm{m}$ asl), and are so cold, so shorter in ice-free periods, and so scarce in food resources, that the colonization, dispersal ability, and development of their macroinvertebrates are markedly affected (de Mendoza and Catalán, 2010; Catalán and Donato-Rondón, 2016). As a result, the significantly lower macroinvertebrate biodiversity indices recorded in the R Alps, almost certainly, reflect the inability of most aquatic taxa to colonize and sustain populations at the highest altitudes.

As for diatoms, the most frequent and abundant taxa found in the study area are common elements of epilithic communities, with benthic or epontic species well adapted to survive to long ice covered periods. Achnanthidium

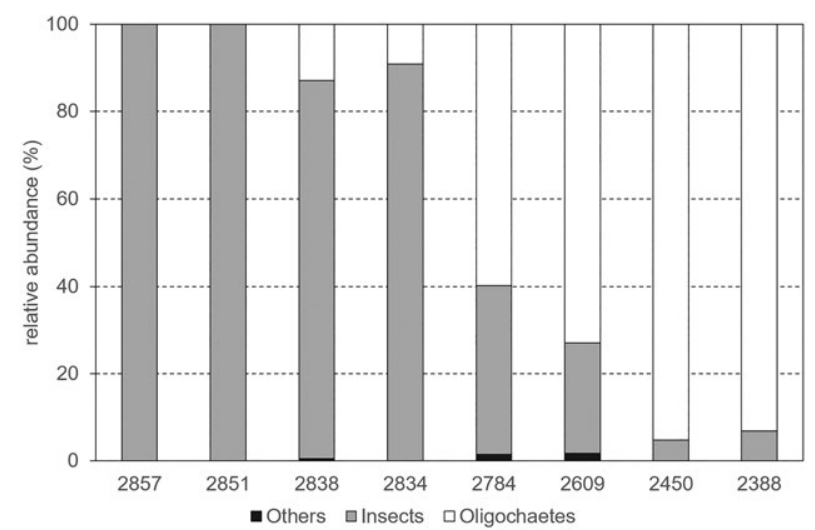

Fig. 7. Main macroinvertebrates groups distribution along an altitudinal gradient in the SNP area. minutissimum, Encyonema minutum, and Cymbella affinis are indeed largely diffused in Central Europe and in the Alpine regions, and considered highly sensitive according to most diatom indices (Lecointe et al., 1993).

The altitudinal/temperature gradient in our data set is not large enough to record significant differences in diatom species assemblages. CCA results show that assemblage structure seems to respond mainly to water chemistry rather than to geographic or morphometric features. Even if diatoms are known to be $\mathrm{pH}$-sensitive, in the present work, $\mathrm{pH}$ is not an important key factor, because $\mathrm{R}$ Alps lakes show a limited $\mathrm{pH}$ range (shifted towards higher values), and a quite high buffer capacity. Nutrient concentration and ionic content have a greater effect on species composition respect to $\mathrm{pH}$, reflecting the geological and physical characteristic of substrates. Therefore, the presence of Nitzschia palea, N. frustulum in lakes Rosole and Bianco or of Cymbella affinis in lakes Rosole, Bianco and L2 Pisella suggests a high organic matter and nutrient content. Fragilaria gracilis, the main component of Lake Nero epilithon, is a rheophilic species with wide $\mathrm{pH}$ and solute content requirements. This species prefers fresh-brackish, oligo-mesotrophic $\alpha$ mesosaprobic waters (Antón-Garrido et al., 2013) and can be found both in the plankton community living in ribbonlike aggregates or in the benthic population, clumps like attached to substrates. Its dominance in Lake Nero is likely associated to a slightly higher organic content.

Taking into consideration the distribution of taxa and its link to water level fluctuations, moisture indicator values (van Dam et al., 1994) were given for $62 \%$ of the species found (69 taxa). About $84 \%$ of these taxa occurred mainly in lakes, while $16 \%$ on wet, moist or temporary dry habitats, reaching high abundances in very few cases. Among them, Microcostatus krasskei is an aerophilic freshwater species typical of lithic pseudo-aerial substrates (Johansen and Sray, 1998); it is present in four lakes, but only in Lake Rosole with high abundances, indicating extreme water level fluctuations.

Undemanding nutritional habits, simple structure, fast growth and both sexual and asexual reproduction make diatoms extremely adaptable to various ecological conditions, resulting in their high survival capacity and species biodiversity (Krivograd Klemenčič and Toman, 2010). In Alpine lakes subject to harsh conditions, local factors become important in selecting the community composition. Diversity indices show local differences within the R Alps lakes that are similar to those found in the P-L Alps, and not related to altitude or $\mathrm{pH}$, but probably to ionic and nutrient contents. The same situation is also found in other high mountain lakes in the Adamello-Brenta Regional Park (Tolotti, 2001), where diatom assemblages are characterised by taxa belonging to genera Navicula, Achananthes, Cymbella s.l. and 
Pinnularia, and where no significant correlation is found between species diversity and environmental variables. In our opinion, spatial and temporal changes of physical and chemical characteristics affect the presence of ecological niches, with cascade effects on species occurrences, abundances, and on their assemblage structure.

According to the German Diatom Red List, all lakes in the Rhaetian Alps can be considered refuges for several taxa classified as endangered or decreasing (at least 10\% of species in each lake). In particular, lakes L1 Rosole and Manzina, characterised by highly mineralized waters, present very high percentages $(>45 \%)$ of these species. In general, endangered species show very low abundances and frequencies: the only exceptions are Brachysira vitrea and Rossithidium petersenii (found in $38 \%$ of lakes), and Microcostatus krasskei (found in 50\% of lakes).

However, according to Falasco and Bona (2011), a comparison with the Red List could present some shortcomings since the list has not been updated since 1996, it is based on regional data, and for a large number of species information is still lacking. Thus, further indepth studies will allow to update and validate the Red List data set for the Italian Alps.

\section{CONCLUSIONS}

The SNP lakes revealed a wide chemical variability even in limited geographical areas, both as regards major ion and nutrient concentrations. In these lakes, 36 macroinvertebrates taxa and 111 diatoms taxa were collected along the lake shorelines. The taxa identified were ubiquitous and frequent along the Alps and most of them were represented by cold-stenothermal species.

The comparison with P-L Alps lakes showed that: i) the altitudinal/temperature gradient is of particular interest for the distribution of insects, contributing to their dominance on oligochaetes at the highest elevations; ii) unlike what observed for the benthic community, the altitudinal gradient here considered is not so extensive as to influence the diversity of diatoms, so that their current assemblage structure is comparable throughout the Alpine region; iii) the lakes in the R Alps represent an exception for macroinvertebrate biodiversity because of their very high elevation. This insight cannot be regarded as valid for diatoms assemblages because iv) they respond mainly to water chemistry (nutrients and ionic content).

Lake chemical and biological surveys, like the one here presented, allow to get information on the ecological status of high altitude lakes, and on the local key factors driving their biological diversity.

The global change scenario predicts an increase in temperature in the Alpine region (Gobiet et al., 2014), resulting in a reduction of snow cover and the thawing of the cryosphere. These will induce an increase in ionic content and in lake water turbidity, and more pronounced water level fluctuations (Preston et al., 2016). In the near future, these variations are expected to impact on macroinvertebrates and diatoms with: i) shifts towards euryhaline and aerophilic species, ii) losses of sensitive species, and ultimately iii) alterations of biodiversity (Sommaruga, 2015; Hotaling et al., 2017). Hence, these new data in the SNP will represent a benchmark to directly measure the climate change impacts in these high altitude habitats.

\section{ACKNOWLEDGMENTS}

The present research was conducted within the Project "SHARE Stelvio - un Parco Osservatorio per lo studio dei Cambiamenti Climatici e Ambientali in alta quota" supported by the Lombardy Region under the umbrella agreement between the Lombardy Region and the Lombardy Foundation for the Environment (FLA). We would like to thank the staff of CNR-IRSA involved in fieldwork and analysis, and Drs. Alejandro Martinez and Laura Garzoli (CNR-IRSA) for language revision.

\section{REFERENCES}

AA.VV., 1977-1985. [Guide per il riconoscimento delle specie animali delle acque interne italiane].[Books in Italian]. Collana del progetto finalizzato 'Promozione della qualità dell'ambiente', 29 volumi. CNR Edizioni, Rome.

Abraham J, Allen P, Dunbar J, Dworkin S, 1999. Sediment type distribution in reservoirs: sediment source versus morphometry. Environ. Geol. 38:101-110.

APAT, IRSA-CNR, 2003. [Metodi analitici per le acque].[Book in Italian]. IRSA-CNR: $1153 \mathrm{pp}$.

APHA, AWWA, WEF, 2005. Standard methods for the examination of water and wastewater. (Method $4110 \mathrm{~B}$ ). American Public Health Association, Washington.

Antón-Garrido B, Romo S, Villena MJ, 2013. Diatom species composition and indices for determining the ecological status of coastal Mediterranean Spanish lakes. Anales Jard. Bot. Madrid 70:122-135.

Bale JS, 2002. Insects and low temperatures: from molecular biology to distributions and abundance. Philos. T. R. Soc. B 357:849-862.

Battarbee RW, 1986. Diatom analysis, p 527-570. In: B.E. Berglund (ed.), Handbook of Holocene paleoecology and paleohydrology. J. Wiley \& Sons, London

Battarbee RW, Kernan M, Rose NL, 2009. Threatened and stressed mountain lakes of Europe: assessment and progress. Aquat. Ecosyst. Health Manag. 12:118-128.

Battarbee RW, Jones VJ, Flower RJ, Cameron NG, Bennion H, Carvalho L, Juggins S, 2001. Diatoms, p. 155-202. In: J. Smol, H.J.B. Birks and W. Last (eds.), Tracking environmental change using lake sediments. 3. Terrestrial, algal, and siliceous indicators. Kluwer Academic Publ., Dordrecht. 
Bennion H, Burgess A, Juggins S, Kelly M, Reddihough G, Yallop M, 2012. Assessment of ecological status in UK lakes using diatoms. Science Report SC070034/TR3, Environment Agency, Bristol.

Boggero A, 2018. Macroinvertebrates of Italian mountain lakes: a review. Redia - Journal of Zoology 101:35-45.Boggero A, Füreder L, Lencioni V, Simcic T, Thaler B, Ferrarese U, Lotter AF, Ettinger R, 2006. Littoral Chironomid communities of Alpine lakes in relation to environmental factors. Hydrobiologia 562:145-165.

Boggero A, Zaupa S, Rossaro B, Lencioni V, Gherardi F, 2011. [Guida tecnica alla programmazione del campionamento e alla scelta della strumentazione idonea per lo studio della fauna macroinvertebrata lacustre].[Report in Italian]. CNRISE: $64 \mathrm{pp}$.

Box GEP, Cox DR, 1964. An analysis of transformations. J. Roy. Stat. Soc. B 26:211-252.

Brinkhurst RO, Jamieson BGM, 1971. Aquatic Oligochaeta of the world. Oliver \& Boyd, Edimburgh: 860 pp.

Cantonati M, Kelly MG, Lange-Bertalot H, 2017. Freshwater benthic diatoms of central europe: over 800 common species used in ecological assessment. Koeltz Botanical Book, Oberreifenberg: $942 \mathrm{pp}$.

Catalán J, Camarero L, Felip M, Pla S, Ventura M, Buchaca T, Bartumeus F, de Mendoza G, Miró A, Casamayor EO, Medina-Sánchez JM, Bacardit M, Altuna M, Bartrons M, Díaz de Quijano D, 2006. High mountain lakes: extreme habitats and witnesses of environmental changes. Limnetica 25:551-584.

Catalán J, Curtis C, Kernan M, 2009. Remote European mountain lake ecosystems: regionalisation and ecological status. Freshwater Biol. 54:2419-2432.

Catalán J, Donato-Rondón J, 2016. Perspectives for an integrated understanding of tropical and temperate highmountain lakes. J. Limnol. 75:215-234. DOI: 10.4081/jlimnol. 2016.1372.

CEN (Comité Européen de Normalisation), 2003. Water quality. Guidance standard for the routine sampling and pretreatment of benthic diatoms from rivers. EN 13946:2003. CEN, Geneva.

Čiamporová-Zat'ovičová Z, Hamerlík L, Šporka F, Bitušík P, 2010. Littoral benthic macroinvertebrates of alpine lakes (Tatra Mts) along an altitudinal gradient: a basis for climate change assessment. Hydrobiologia 648:19-34.

Chatterjee S, Hadi AS, Price B, 2000. Regression analysis by example. 3. J. Wiley \& Sons, New York.

de Mendoza G, Catalán J, 2010. Lake macroinvertebrates and the altitudinal environmental gradient in the Pyrenees. Hydrobiologia 648:51-72.

Dell'Uomo A, Pedrotti F, Di Giovanni MV, Taticchi MI, Tiberi O, 1980. [Studio idrobiologico del Lago Bianco (Parco Nazionale dello Stelvio)].[Article in Italian]. Quaderni del Parco Nazionale dello Stelvio 2:67-95.

Descy JP, Coste M, 1991. A test of methods for assessing water quality based on diatoms. Verh. Int. Ver. Limnol. 24:21122116.

Dumnicka E, 1994. Communities of oligochaetes in mountain streams of Poland. Hydrobiologia 278:107-110.

Escudero-Oñate C, 2017. Intercomparison 1731: $\mathrm{pH}$, Conductivity, Alkalinity, NO3-N, Cl, SO4, Ca, Mg, Na, K,
TOC, Al, Fe, Mn, Cd, Pb, Cu, Ni, and Zn. ICP Waters Report $134 / 2017$.

Falasco E, Bona F, 2011. Diatom community biodiversity in an Alpine protected area: a study in the Maritime Alps Natural Park. J. Limnol. 70:157-167. DOI: 10.4081/jlimnol.2011.157.

Fjellheim A, Boggero A, Nocentini AM, Rieradevall M, Raddum GG, Schnell ØA, 2000. Distribution of benthic invertebrates in relation to environmental factors. A study of European remote alpine lake ecosystems. Verh. Int. Ver. Limnol. 26:484-488.

Fjellheim A, Raddum GG, Vandvik V, Cogalniceanu D, Bitusik P, Boggero A, Brancelj A, Dumnicka E, Galas J, Gâldean N, Kownacki A, Preda E, Rîsnoveanu G, Sporka F, Stuchlik E, Vidinova Y, 2009. Diversity and distribution patterns of benthic invertebrates along alpine gradients. A study of remote European freshwater lakes. Advanc. Limnol. 62:167190.

Forasacco E, 1998-1999. [Morfologia ed ecologia di alcune aree proglaciali dell'Alta Valtellina].[Thesis in Italian]. University of Milan.

Füreder L, Ettinger R, Boggero A, Thaler B, Thies H, 2006. Macroinvertebrate diversity in Alpine lakes: effects of altitude and catchment properties. Hydrobiologia 562:123144.

Gauch HG, 1982. Multivariate analysis in community ecology. Cambridge University Press, Cambridge: 298 pp.

Giussani G, de Bernardi R, Mosello R, Origgi I, Ruffoni T, 1986. [Indagine limnologica sui laghi alpini d'alta quota].[Article in Italian]. Documenta Ist. Ital. Idrobiol. 9: 415 pp.

Gobiet A, Kotlarski S, Beniston M, Heinrich G, Rajczak J, Stoffel M, 2014. 21st century climate change in the European Alps: a review. Sci. Total Environ. 493:1138-1151.

Grigelis A, 1980. Ecological studies of aquatic oligochaetes in the USSR, p. 225-240. In: R.O. Brinkhurst and D.G. Cook (eds.), Aquatic Oligochaete Biology. Plenum Press, New York.

Hamerlík L, Svitok M, Novikmec M, Veselska M, Bitušík P, 2017. Weak altitudinal pattern of overall chironomid richness is a result of contrasting trends of subfamilies in high-altitude ponds. Hydrobiologia 793:67-81.

Hope ACA, 1968. A simplified Monte Carlo significance test procedure. J. Roy. Stat. Soc. B 30:582-598.

Hotaling S, Tronstad LM, Cody Bish J, 2017. Macroinvertebrate richness is lower in high-elevation lakes vs nearby streams: evidence from Grand Teton National Park, Wyoming. J. Nat. Hist. 51:29-30.

ICP Waters Programme Centre, 1996. Programme manual. NIVA report SNO 3547-96.

ICP Waters Programme Centre, 2010. ICP Waters Programme Manual 2010. NIVA SNO 6074-2010. ICP Waters report $105 / 2010$.

Jacobsen D, Milner AM, Brown LE, Dangles O, 2012. Biodiversity under threat in glacier-fed river systems. Nat. Clim. Change 2:361-364.

Johansen JR, Sray JC, 1998. Microcostatus gen. nov., a new aerophilic diatom genus based on Navicula krasskei Hustedt. Diatom Res. 13:93-101.

Jyväsjärvi J, Boros G, Jones RI, Hämäläinen H, 2013. The importance of sedimenting organic matter, relative to oxygen and temperature, in structuring lake profundal macroinvertebrate assemblages. Hydrobiologia 709:55-72. 
Kamenik C, Schmidt R, Kum G, Psenner R, 2001. The influence of catchment characteristics on the water chemistry of mountain lakes. Arct. Antarct. Alp. Res. 33:404-409.

Kelly MG, Cazaubon A, Coring E, Dell'uomo A, Ector L, Goldsmith B, Guasch H, Hürlimann J, Jarlman A, Kawecka B, Kwandrans J, Laugaste R, Lindstrøm E-A, Leitao M, Marvan P, Padisák J, Pipp E, Prygiel J, Rott E, Sabater S, van Dam H, Vizinet J, 1998. Recommendations for the routine sampling of diatoms for water quality assessments in Europe. J. Appl. Phycol. 10:215-224.

Kelly MG, Gómez-Rodríguez C, Kahlert M, Almeida SFP, Bennett C, Bottin M, Delmas F, Descy J-P, Dörflinger G, Kennedy B, Marvan P, Opatrilova L, Pardo I, Pfister P, Rosebery J, Schneider S, Vilbaste S, 2012. Establishing expectations for pan-European diatom based ecological status assessments. Ecol. Ind. 20:177-186.

King L, Barker P, Jones RI, 2000. Epilithic algal communities and their relationship to environmental variables in lakes of the English Lake District. Fresh. Biol. 45: 425-442.

Krammer K, Lange-Bertalot H, 1986-1991. [Süsswasserflora von Mitteleuropa. 2.].[Book in German]. Gustav Fischer Verlag, Stuttgart.

Krammer K, 2000. Diatoms of Europe. 1. The genus Pinnularia. Gantner Verlag, Kommanditges., Königstein: 703 pp.

Krivograd Klemenčič A, Toman MJ, 2010. Influence of environmental variables on benthic algal associations from selected extreme environments in Slovenia in relation to the species identification. Period. Biol. 112:179-191.

Kruskal WH, Wallis WA, 1952. Use of ranks in one-criterion variance analysis. J. Am. Stat. Assoc. 47:583-621.

Kwandrans J, 2007. Diversity and ecology of benthic diatom communities in relation to acidity, acidification and recovery of lakes and rivers. A.R.G. Gantner Verlag K.G., Königstein: 168 pp.

Lange-Bertalot H, 1996. [Rote Liste der limnischen Kieselalgen (Bacillariophyceae) Deutschlands].[Article in German]. Schriftenr. Vegetationsk. 28:633-677.

Lecointe C, Coste M, Prygiel J, 1993. Omnidia: Software for taxonomy, calculation of diatom indices and inventories management. Hydrobiologia 269-270:509-513.

Lods-Crozet B, Oertli B, Robinson CT, 2012. Long-term patterns of chironomid assemblages in a high elevation stream/lake network (Switzerland): Implications to global change. Proceedings 18th Int. Symp. on Chironomidae. Fauna Norvegica 31:71-85.

Ludwig G, Haupt H, Gruttke H, Binot-Hafke M, Otto C, Pauly A, 2009. [Rote Liste gefährdeter Tiere, Pflanzen und Pilze Deutschlands. Band 1: Wirbeltiere].[Book in German]. Landwirtschaftsvlg Münster: 386 pp.

Marazzi S, 2005. [Atlante orografico delle Alpi. SOIUSA. Suddivisione orografica internazionale unificata del Sistema Alpino].[Book in Italian]. Priuli \& Verlucca, Torino: 416 pp.

Marchetto A, Mosello R, Psenner R, Bendetta G, Boggero A, Tait D, Tartari GA, 1995. Factors affecting water chemistry of alpine lakes. Aquat. Sci. 57:81-89.

Marchetto A, Rogora M, Boggero A, Musazzi S, Lami A, Lotter AF, Tolotti M, Thies H, Psenner R, Massaferro J, Barbieri A, 2009. Response of Alpine lakes to major environmental gradients, as detected through planktonic, benthic and sedimentary assemblages. Adv. Limnol. 62:419-440.
Marziali L, Rossaro B, 2013. Response of chironomid species (Diptera, Chironomidae) to water temperature: effects on species distribution in specific habitats. J. Entomol. Acarol. Res. 45:73-89.

Moller Pillot HKM, 2009. Chironomidae larvae of the Netherlands and adjacent lowlands. II. Biology and ecology of the Chironomini. KNNV Publishing, Zeist: 270 pp.

NIVA, 1987. International cooperative programme for assessment and monitoring of acidification of rivers and lakes: Programme Manual. Programme Centre, NIVA: 23 pp.

Pielou EC, 1966. The measurement of diversity in different types of biological collections. J. Theor. Biol. 13:131-144.

Poma G, Salerno F, Roscioli C, Novati S, Guzzella L, 2017. Persistent organic pollutants in sediments of high-altitude Alpine ponds within Stelvio National Park, Italian Alps. Inland Waters 7:34-44.

Preston DL, Caine N, McKnight DM, Williams MW, Hell K, Miller MP, Hart SJ, Johnson PTJ, 2016. Climate regulates alpine lake ice cover phenology and aquatic ecosystem structure. Geophys. Res. Lett. 43:5353-5360.

Rogora M, Colombo L, Lepori F, Marchetto A, Steingruber S, Tornimbeni O, 2013. Thirty years of chemical changes in alpine acid-sensitive lakes in the Alps. Water Air Soil Poll. 224:1746.

Rogora M, Massaferro J, Marchetto A, Tartari GA, Mosello R, 2008. The water chemistry of Northern Patagonian lakes and their nitrogen status in comparison with remote lakes in different regions of the globe. J. Limnol. 67:75-86.

Rokach L, Maimon O, 2005. Clustering methods, p. 321-352. In: O. Maimon, L. Rokach, (eds.), Data mining and knowledge discovery handbook. Springer.

Rosenberg DM, Resh VH, 1993. Introduction to freshwater biomonitoring and benthic macroinvertebrates, p. 1-9. In: D.M. Rosenberg and V.H. Resh (eds.), Freshwater biomonitoring and benthic macroinvertebrates. Chapman Hall, New York.

Rossaro B, 1991. Chironomids and water temperature. Aquat. Insects 13:87-98.

Rotta F, Cerasino L, Occhipinti-Ambrogi A, Rogora M, Seppi R, Tolotti M, 2018. Diatom diversity in headwaters influenced by permafrost thawing: First evidence from the Central Italian Alps. Adv. Oceanogr. Limnol. 9:79-96.

Salerno F, Gambelli S, Viviano G, Thakuri S, Guyennon N, D'Agata C, Diolaiuti G, Smiraglia C, Stefani F, Bocchiola D, Tartari G, 2014. High alpine ponds shift upwards as average temperatures increase: a case study of the OrtlesCevedale mountain group (Southern Alps, Italy) over the last 50 years. Global Planet Change 120:81-91.

Shannon CE, Weaver W, 1948. The mathematical theory of communication. University of Illinois Press, Urbana: $132 \mathrm{pp}$.

Simpson EH, 1949. Measurement of diversity. Nature 163:688 pp.

Schmelz RM, Collado R, 2010. A guide to European terrestrial and freshwater species of Enchytraeidae (Oligochaeta). Soil Organisms 82:176 pp.

Schmelz RM, Collado R, Römbke J, 2015. Cognettia Nielsen \& Christensen, 1959 (Annelida, Oligochaeta, Enchytraeidae): proposed precedence over Euenchytraeus Bretscher, 1906 and Chamaedrilus Friend, 1913. Bull. Zool. Nomencl. 72:186-192.

Sommaruga R, 2015. When glaciers and ice sheets melt: 
consequences for planktonic organisms. J. Plankton Res. 37:509-518.

ter Braak CJF, Šmilauer P, 2002. CANOCO reference manual and CanoDraw for Windows. User's guide (version 4.5). University of Wageningen: $499 \mathrm{pp}$.

Tiberti R, Rogora M, Tartari GA, Callieri C, 2014. Ecological impact of transhumance on the trophic state of alpine lakes in Gran Paradiso National Park. Knowl. Manag. Aquat. Ec. 415:05.

Timm T, 2009. A guide to the freshwater Oligochaeta and Polychaeta of Northern and Central Europe. Mauch Verlag, Dinkelscherben: $235 \mathrm{pp}$.

Tolotti M, 2001. Littoral diatom communities in high mountain lakes of the Adamello-Brenta Regional Park (Trentino, Italy) and their relation to acidification, p. 327-352. In: R.
Jahn, J.P. Kociolek, A. Witkowski and P. Compère (eds.), Studies on Diatoms, Lange-Bertalot-Festschrift. Gantner, Ruggell.

UNI, 2014. [Qualità dell'acqua - Guida per il campionamento di routine e la preparazione di diatomee bentoniche da fiumi e laghi].[in Italian]. Norm EN 13946. UNI, Milan.

van Dam H, Mertens A, Sinkeldam J, 1994. A coded checklist and ecological indicator values of freshwater diatoms from the Netherlands. Neth. J. Aquat. Ecol. 28:118-133.

Wiederholm T, 1983. Chironomidae of the Holartic region. Keys and Diagnoses. Part I: Larvae. 19. Entomol. Scand. Suppl.: $457 \mathrm{pp}$.

Wiederholm T, 1986. Chironomidae of the Holartic region. Keys and Diagnoses. Part II: Pupae. 28. Entomol. Scand. Suppl.: $482 \mathrm{pp}$. 